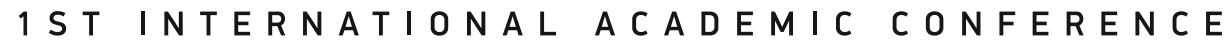
PLACES AND TECHNOLOGIES 2014

\begin{tabular}{l|l|l}
\hline BELGRADE, 3-4. APRIL 2014 & KEEPING UP WITH TECHNOLOGIES TO IMPROVE PLACES \\
\hline
\end{tabular}

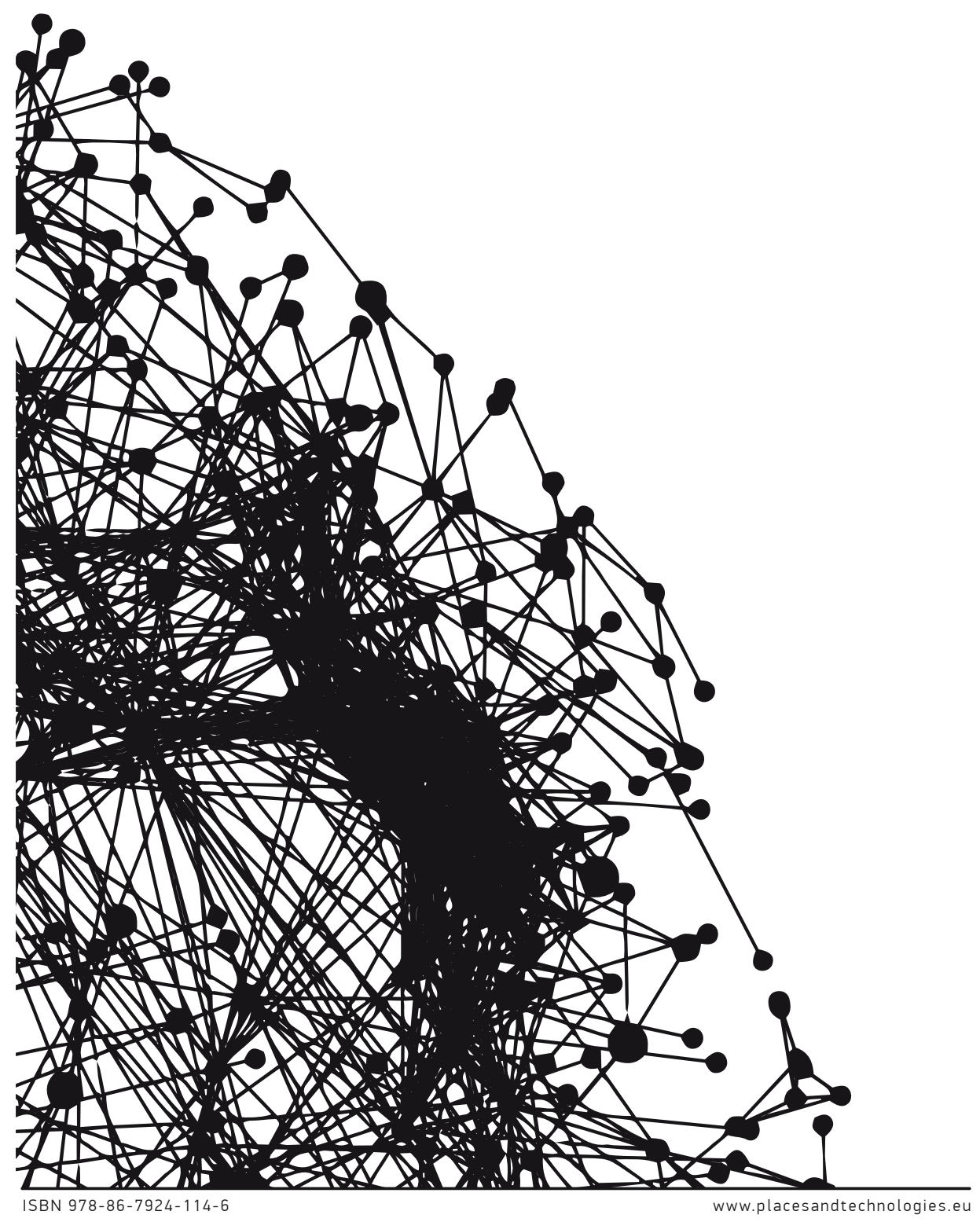




\section{Proceedings of INTERNATIONAL ACADEMIC CONFERENCE ON PLACES AND TECHNOLOGIES}

April 3-4, 2014, Belgrade, Serbia 


\section{PLACES AND TECHNOLOGIES 2014}

\section{Proceedings of First International Academic Conference on Places and TECHNOLOGIES}

International Academic Conference on Places and Technologies, Places and Technologies 2014, will be the first conference organized by Univerisity of Belgrade Faculty of Architecture, Professional association Urban Laboratory and University of Belgrade - Faculty of Philosophy.

Editors: Dr Eva Vaništa Lazarević, Dr Aleksandra Krstić-Furundžić, Dr Aleksandra Đukić and Dr Milena Vukmirović

For publisher: Dr Vladan Đokić

Publisher: University of Belgrade - Faculty of Architecture

Design: Stanislav Mirković

Place and year: Belgrade 2014

ISBN 978-86-7924-114-6 
CIP - Каталогизација у публикацији

Народна библиотека Србије, Београд

711.4.01(082)(0.034.2)

711.4:005.591.6(082)(0.034.2)

INTERNATIONAL Academic Conference on Places

and Technologies (1st ; 2014 ; Belgrade)

Places and Technologies 2014 [Elektronski

izvori] : keeping up with technologies to

improve places : conference proceedings : 1 st international academic conference, Belgrade, 3-4. April 2014 / [organized by Univerisity of Belgrade - Faculty of Architecture,

Professional Association Urban Laboratory and University of Belgrade - Faculty of

Philosophy] ; editors Eva Vaništa Lazarević

... [et al.]. - Belgrade : Faculty of

Architecture, 2014 (Belgrade : Faculty of

Architecture). - 1 USB fleš memorija ; 1 x 2

$\mathrm{x} 14 \mathrm{~cm}$

Sistemski zahtevi: Nisu navedeni. - Nasl. sa

naslovnog ekrana. - Tiraž 150. -

Bibliografija uz svaki rad.

ISBN 978-86-7924-114-6

1. Vaništa Lazarević, Eva, 1961- [уредник]

2. Faculty of Architecture (Belgrade)

a) Градови - Мултидисциплинарни приступ -

Зборници b) Урбанистичко планирање -

Технолошки развој - Зборници

COBISS.SR-ID 206380812 
Organizers

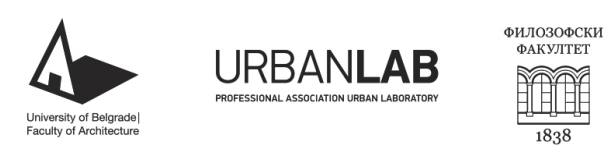

GENERAL SPONSOR

\section{Telekom Srbija}

SPONSORS

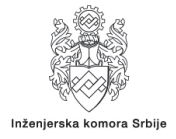
INSTI'UT'S

SERBIE

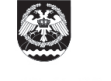

Arhi.pro

PHILIPS

$\square$

Foundation

Dokukino

DONATORS

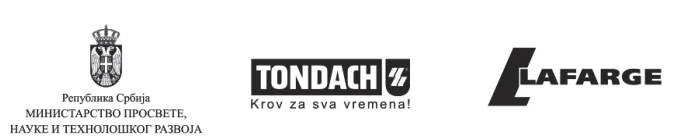

SUPPORTERS

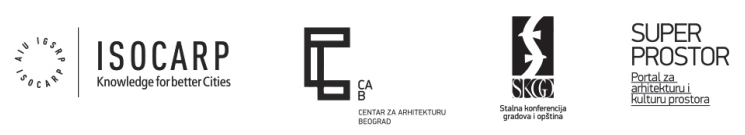




\section{CONTENTS}

PART I: URBANISM

Urban planning and technologies

OVERCOMING BARRIERS TO GROWTH

Stephen Platt

URBAN CHALLENGES OF ENERGY EFFICIENCY AND CONTEXTSENSITIVE PLANNING APPROACHES IN BULGARIA

Elena Dimitrova

NEW URBAN PROTOCOLS FOR FRAGMENTED TERRITORIES _ THE EXAMPLE OF WESTERN THESSALONIKI

Styliani Rossikopoulou-Pappa, Valia Fragkia

A FEASIBILITY STUDY FOR A TECHNOLOGICAL PARK IN FALCONARA MARITTIMA AN, ITALY

Giovanni Sergi

SAVING URBAN PLANNING FROM ANOTHER UTOPIAN MODEL

Danijela Milojkić, Marija Maruna

THE IMPLICATIONS OF DIGITAL TECHNOLOGY ON THE PERCEPTION OF CENTRALITY

Mihai Alexandru, Cătălina Ioniță

TECHNOLOGY AND LANDSCAPE: REDUCE, REUSE AND RECYCLE THE MINING DROSSCAPES

Nicola Martinelli, Francesco Marocco, Alessandro Reina, Maristella Loi, Federica Greco

THE ILLEGAL SETTLEMENTS IN BELGRADE VS. TAMING CITY GROWTH: CASE STUDY OF BELGRADE

Biserka Mitrović, Miodrag Ralević, Branislav Antonić

IMPACT OF CLIMATE CHANGE IN URBAN PLANNING

Tamara Tošić

CONCEPT OF URBAN VILLAGE: THE APPLICATION OF THE CONCEPT AS A FOUNDATION FOR NEW TYPOLOGY OF URBAN VILLAGES

Branislav Antonić

RESILIENCE AND VULNERABILITY OF URBAN SYSTEMS. A METHODOLOGICAL PROPOSAL FOR SEISMIC RISK MITIGATION 
Urban design and technologies

PUBLIC PLACES AND SPLIT DEVELOPMENT MODEL

Višnja Kukoč

103

AGILE LANDSCAPES: REDESIGNING URBAN SPACE

Anastasios Tellios, Despoina Zavraka

110

PLANNING AND DESIGNING SAFE AND SECURE OPEN PUBLIC SPACES IN SERBIA

Svetlana Stanarević, Aleksandra Djukic

SPATIAL AND FUNCTIONAL TRANSFORMATION OF BUSINESS AREAS UNDER THE IMPACT OF INFORMATION TECHNOLOGIES CASE STUDY OF NIŠ ADMINISTRATIVE DISTRICT

Aleksandar Ristić, Petar Mitković

THE IMPACT OF NEW TECHNOLOGIES ON CITY ACUPUNCTURE METHODOLOGY AND INTERVENTIONS

Kristina Careva, Rene Lisac

COMFORT OF OPEN PUBLIC SPACES: CASE STUDY NEW BELGRADE

Aleksandra Djukic, Nevena Novakovic

005 PUBLIC ART IN BERLIN

Biljana Arandjelovic

PROTECTION OF PERSON WHIT DISABILITIES: IMPLEMENTATION OF ACCESSIBILITY STANDARDS

Dragana Vasiljevic Tomic, Radojko Obradović

VERTICAL PUBLIC SPACE

Sorana Cornelia Radulescu, Roger Riewe

READY-AVAILABLE HYBRID METHODOLOGIES FOR CONTEMPORARY PUBLIC SPACE RESEARCH

Milena Ivkovic, Berit Piepgras, Robin van Emden

RETAIL - NEW TECHNOLOGIES AND URBAN CENTRALITY

Martin Brabant

TECHNOLOGY AND NEOLIBERAL URBAN PLACES

Marija Cvjetković

NEURAL CITIES OR HOW CITIES TEACH US TO DESIGN THEM

BETTER

Angelica Stan

MORPHOLOGICAL AND TYPOLOGICAL CLASSIFICATION OF GREEN STREET FORMS: MLADEN STOJANOVIC STREET IN BANJA LUKA

Tanja Trkulja 
Urban regeneration and tehenology

PROPERTY ISSUES IN THE TURKISH URBAN REGENERATION

PROJECTS

Mehmet Çete, Yunus Konbul

URBAN ENERGY AND URBAN REGENERATION STRATEGIES:

EVALUATION OF IZMIR-UZUNDERE URBAN REGENERATION PROJECT

Yakup Egercioğlu, Çilem Türkmen

THE EMPTY URBAN SPACES AS AN OPPORTUNITY FOR THE CITY

TO REINVENT ITSELF: THE CASE OF THE INDUSTRIAL

TECHNOLOGICAL OBSOLETENESS

Cătălina Ioniță, Mihai Alexandru

ENHANCEMENT OF URBAN LIFE QUALITY IN URBAN

REGENERATION PROJECTS: IZMIR-BAYRAKLI URBAN

REGENERATION PROJECT

Yakup Egercioğlu, Tuğçe Ertan

THE INDUSTRIAL BUILDINGS WHICH USED IN SAUDI ARABIA AND SUSTAINABILITY

Wael Al-Buzz

AN OVERVIEW OF URBAN REGENERATION PROJECTS IN TURKEY

Yunus Konbul, Mehmet Çete

ART AND CULTURE AS INITIATORS OF ARCHITECTURAL AND URBAN TRANSFORMATION IN SAVAMALA

Ksenija Pantović, Iva Čukić, Jasna Kavran

Smart cites/regions and network protocols

SMART CITY GRAZ: FROM THE VISION TO THE ACTION

Carlos Varela Martín, Ernst Rainer, Hans Schnitzer

RESIDENTS INTERACTION WITH HOME RESOURCES

Cerasela Dinu, Constantin-Daniel Oancea

RENEWABLE AND DISTRIBUTED SOURCES WITHIN SMART ENERGY REGIONS

Jovan Todorovic

THE SMART CITY FOR THE FUTURE. HOW A SPATIALLY ENABLED AFFECTED BY THE URBAN POPULATION?

Shahryar Habibi

PERFORMANCE EVALUATION OF ROUTING PROTOCOLS FOR ADHOC NETWORKS

Ledina Karteri, Valma Prifti 
SMART CITIES AND CHALLENGES OF SUSTAINABILITY

Rigels Pirgu

A FUZZY BASED CALL CONTROL SYSTEM IN MOBILE NETWORKS, CONSIDERING PRIORITY COMMUNICATIONS

Valma Prifti, Ledina Karteri

Historical centers, Building heritage and Technologies

ICT AND VGI TO PROMOTE MINOR HISTORIC CENTRES AND THEIR LANDSCAPE

Pierangela Loconte, Francesco Rotondo

THE SUSTAINABILITY AND CULTURAL HERITAGE MANAGEMENT

Christian Kersten Hofbauer, Elham Madadi Kandjani, Jean Marie Corneille Meuwissen

CONCEPTS OF FORMING OF URBAN SOLUTIONS IN HOUSING

SETTLEMENTS IN BELGRADE BUILT IN PRECAST INDUSTRIALIZED SYSTEMS IN SECOND HALF OF XX CENTURY

Dragana Mecanov

NEW ARCHITECTURE IN HISTORICAL CENTRES

Alessandro Bruccoleri

INFORMATION AND COMMUNICATION TECHNOLOGIES TO IMPROVE THE KNOWLEDGE OF PLACES. THE ROME HISTORICAL CENTRE AS A CASE STUDY

Francesca Geremia

CONTEMPORARY INTERVENTIONS IN HISTORIC PLACES _ THE

EXAMPLE OF THESSALONIKI METRO

Stavros Apotsos

Image and Identity of place

THE IMAGE OF TRIFKOVIĆ SQUARE (NOVI SAD, SERBIA) THEN AND NOW

Ivana Blagojević, Ksenija Hiel

IDENTITY OF NEW MEDIA SPACES

Jelena Brajković, Lidija Đokić

THESSALONIKI: A MULTICULTURAL ARCHITECTURAL DESTINATION

Niki Manou-Andreadis, Maria Milona

ELEMENTS OF IDENTITY AND UNUSED POTENTIALS OF CENTRAL ZONE IN NOVI SAD

Milena Krklješ, Dijana Apostolović, Aleksandra Milinković 
BELGRADE SKYLINE: CONTINUITY, PARADOXES \& DESIRES

Vladimir Milenković, Snežana Vesnić, Tatjana Stratimirović

CITY OF THE MIND - INVISIBLE IN THE MAP

Jelena Stankovic, Milenko Stankovic

WHAT MAKES A PLACE?

Saskia I. de Wit, Denise Piccinini

SUSTAINABILITY, IDENTITY AND ROLE OF TRADITIONAL

MATERIALS

Olivera llić Martinović, Mirjana Miletić

IDENTITY OF URBAN SPACES; ASSESSMENT AND EVALUATION

Elham Madadi-Kandjani, Christian Kersten Hofbauer, Jean Marie Corneille Meuwissen

IMAGE OF SUSTAINABLE PLACES

Vladimir Parežanin, Miloš Mihajlović

PRESERVATION OF IDENTITY OF SPACE WITHIN RAPID ECONOMIC AND TECHNOLOGICAL DEVELOPMENT OF TOURIST DESTINATIONS IN THE EXAMPLE OD JIJOCA DE JERICOACOARA IN BRAZIL

Maja Momirov

PART II: ARCHITECTURE AND TECHNOLOGIES

Sustainability, Sustainable buidings and technologies

SUSTAINABLE RETROFITTING OF EXISTING AND HISTORIC BUILDINGS

Marina Traykova, Tanya Chardakova

OSMOTIC LANDSCAPES - RECOVERED IDENTITIES

Venetia Tsakalidou, Anastasia Papadopoulou

DESIGN SCENARIOS FOR AN OFFICE BUILDING - ENERGY AND ENVIRONMENTAL ASPECTS

Aleksandra Krstic-Furundzic, Tatjana Kosic

TECHNOLOGICAL AND ENVIRONMENTAL ASPECTS OF RAPID HOUSING CONSTRUCTION

Nikola Macut, Bojana Stanković, Nataša Ćuković-Ignjatović

ENERGY ANALYSIS AND REFURBISHMENT STRATEGY FOR ZAGREB UNIVERSITY BUILDINGS: FORMER FACULTY OF TECHNOLOGY IN ZAGREB BY ALFRED ALBINI

Stanka Ostojić, Zoran Veršić, Iva Muraj 
SUSTAINABLE REUSE OF OLD STRATEGIC INFRASTRUCTURE

CANAL DANUBE-TISA-DANUBE

Mirjana Jočić, Nataša Kuburović

PLACE ATTACHMENT AS POTENTIAL FOR SUSTAINABLE LOCAL DEVELOPMENT IN SERBIA

Anđelka Mirkov

LOW ENERGY BUILDINGS: CONCEPT OF ENERGY PERFORMANCE OPTIMIZATION OF SINGLE-FAMILY HOUSES

Katarina Slavković

TECHNOLOGY AND PRODUCTIVE PROCESS: MINING REJECTIONS FROM WASTE TO SUSTAINABLE RESOURCE

Vincenzo Paolo Bagnato, Giovanna Mangialardi, Silvana Milella, Michele Mundo

ADAPTATION OF AN INDUSTRIAL BUILDING INTO HIGHER EDUCATION INSTITUTION IN ACCORDANCE WITH IMPROVED ENERGY PERFORMANCE

Branko Slavković, Komnen Žižić, Danilo Dragović

FUNCTION OF A DESOLATE SPACE

Aleksandra Pešterac, Daniela Dimitrovska

ENVIRONMENT CERTIFICATION OF REHABILITATION DESIGN PROJECTS: PUT AND SHU BUILDINGS AS CASE STUDY

Florian Nepravishta, Gerta Veliu, Ramadan Alushaj

Green strategies and technologies

GREEN URBAN STRATEGIES IN THESSALONIKI IN THE CONTEXT OF CRISIS

Evangelia Athanassiou

GEOSCIENTIFIC EDUCATIVE CENTRE AS SUSTAINABLE COMMUNITIES BUILDING MODEL - POSITIVE COOPERATION EXAMPLE OF LIKA-SENJ COUNTY (CROATIA) AND UNA-SANA COUNTY (BIH)

Ivan Brlić, Anita Bušljeta-Tonković, Katarina Milković

THE OCCUPANTS' PERSPECTIVE AS CATALYST FOR LESS ENERGY INTENSIVE BUILDINGS

Lucia Martincigh, Marina Di Guida, Giovanni Perrucci

THE COLLECTIVE SELF ORGANIZED HOUSING EXPERIENCE IN

ITALY

Silvia Brunoro, Giacomo Bizzarri 
APPLICATION OF ROOF GARDENS IN THE DEFINING IMAGE OF THE CITY

Mirjana Sekulić, Bojana Stanković, Ljiljana Dosenović

STRATEGY FOR NATIONAL DEFINITION OF NEARLY ZERO ENERGY BUILDINGS

Milica Jovanović Popović, Bojana Stanković, Jasna Kavran

ENERGY OPTIMIZATION OF THE BUILDING ENVELOPE OF THE REPRESENTATIVE SAMPLE OF THE EXISTING RESIDENTIAL BUILDING IN BANJA LUKA

Darija Gajić, Aleksandra Krstić - Furundžić

BLUE GREEN DREAM AND DAYLIGHT

Srdjan Stankovic, Cedo Maksimovic, Milenko Stankovic

POSSIBILITIES FOR ENERGY REHABILITATION OF TYPICAL SINGLE FAMILY HOUSE IN BELGRADE - CASE STUDY

Bojana Stanković, Dušan Ignjatović, Nataša Ćuković-Ignjatović

BLUE-GREEN INTEGRATED MODELING SOLUTIONS IN URBAN PLANNING AND ARCHITECTURAL DESIGN

Miloš Mirosavić, Ivana Mirosavić, Srđan Stanković, Čedo Maksimović, Ranko Božović

POTENTIALS AND LIMITATIONS FOR ENERGY REFURBISHMENT OF MULTI-FAMILY RESIDENTIAL BUILDINGS BUILT IN BELGRADE BEFORE THE WORLD WAR ONE

Ljiljana Đukanović, Ana Radivojević, Aleksandar Rajčić

FROM BUILDING INFORMATION MODELS TO SIMPLIFIED GEOMETRIES FOR ENERGY PERFORMANCE SIMULATION

Daniel Ladenhauf, René Berndt, Eva Eggeling, Torsten Ullrich, Kurt Battisti, Markus Gratzl-Michlmair

ENERGY CITY GRAZ - REININGHAUS: FIRST RESULTS FROM AN ENERGY SELF-SUFFICIENT QUARTER

Heimo Staller, Ernst Rainer, Carlos Varela Martín

ENERGY EFFICIENCY AS ADVANCED TECHNOLOGY FOR A SOLUTION TO THE PROBLEM OF DEPOPULATION OF RURAL AREAS IN SERBIA

Jovana Stanišić

THE ENERGY EFFICIENT CITY

Ivan Dochev 
Innovative materials, systems and technology

INVESTIGATION OF FLY ASH INFLUENCE ON CEMENT MORTARS

PROPERTIES

Dragica Jevtić, Aleksandar Savić

INFLUENCE OF GLASS COMPONENT JOINTS ON THE STRUCTURAL GLASS FACADE DESIGN

Aleksandra Krstic-Furundzic, Tatjana Kosic, Jefto Terzovic

QUANTIFYING THE THERMAL BRIDGING EFFECT WITH REGARD TO THE FAÇADE'S CONFIGURATION

Katerina Tsikaloudaki, Theodore Theodosiou, Dimitris Aravantinos, Karolos Nicolaos Kontoleon, Dimitrios Bikas

THE INFLUENCE OF NEW TECHNOLOGIES ON MODERN CITY FACADES

Jasna Čikić Tovarović, Jelena Ivanović Šekularac, Nenad Šekularac

DYNAMIC APPEARANCE OF URBAN AND ARCHITECTURAL SURFACES

Tihana Hrastar, Tamara Marić, Bojana Bojanić

TOWARDS GENERATIVE CONVERGENCE IN DESIGN OF ARCHITECTURAL STRUCTURES

Jelena Milošević, Zoran Šobić, Miodrag Nestorović

APPLICATION OF WOOD AS AN ELEMENT OF FACADE CLADDING IN CONTEMPORARY ARCHITECTURE OF BELGRADE

Jelena Ivanović Šekularac, Jasna Čikić Tovarović, Nenad Šekularac

COMPARISON OF INSOLATION APPLIED ON SURFACES OF MODEL PLACED IN THE AREA OF SKOPJE

Aleksandar Petrovski' Todorka Samardzioska, Ana Trombeva Gavriloska

APPLICATION AND EFFECTS OF PHASE CHANGE MATERIALS IN A MODERN ARCHITECTURAL AESTHETICS

Vladana Stanković, Goran Jovanović, Mirko Stanimirović

INTEGRATED DESIGN OF STRUCTURAL SYSTEMS

Aleksandra Nenadović

NEW COMPOSITE SLAB SYSTEM - LIGHTWEIGHT CONCRETE, STEEL SHEETING AND REINFORCEMENT

Zoran Šobić, Jelena Milošević, Miodrag Nestorović

MODERN METHODS OF STRENGTHENING MASONRY WALLS

Nenad Šekularac, Jasna Čikić Tovarović, Jelena Ivanović Šekularac

NEW PERSPECTIVES FOR FERROCEMENT

Ornela Lalaj, Yavuz Yardım, Salih Yılmaz 
Cultural patterns, Architecture and technologies

SPATIAL AND SOCIAL ASPECTS OF THE ARSENAL

TRANSFORMATION, MILITARY PORT IN TIVAT INTO NAUTICAL TOURISM SETTLEMENT AND PORT „PORTO MONTENEGRO“

Goran Radović

805

DIGITAL FABRICATION IN THE FIELD OF ARCHITECTURE

Roberto Vdović, Morana Pap

816

THE IMPACT OF SMART HOME TECHNOLOGIES ON ARCHITECTURAL DESIGN

Goran Petrović, Marko Aleksendrić

BETWEEN THE PLACE AND NON-PLACE: ARCHITECTURE AND

TERRITORY ON THE EXAMPLE OF SKOPJE

Saša Tasić, Mitko Hadzi Pulja, Minas Bakalchev

INTEGRATED ARCHITECTURAL COMPLEXITY - FROM ABSTRACTION TO TECHNOLOGY AND MATERIALISATION

Rada Čahtarević, Dženana Bijedić, Amra Taso

EVOLUTION DIGITIZED: ARCHITECTURE OF THE SUBLIME DREAM

Mihailo Popović, Vladimir Milenković

MONOCHROMATIC IN THE ARCHITECTURAL COMPOSITION: WITH SPECIAL REFERENCE TO THE APPLICATION OF WHITE COLOUR

Dragana Vasiljevic Tomic, Rifat Alihodzic, Dragana Mojsilovic

(RE)GENERATION \& REFLECTIONS OF THE SCHOOL OF ARCHITECTURE - BANJALUKA IN THE CENTURY OF KNOWLEDGE AND SKILLS

Milenko Stanković, Una Umićević

QUANTUM ARCHITECTURE, NON-PLACE AND ACCULTURATION

Dubravko Aleksić

PLACES AND PRACTICES OF CONSUMPTION IN THE POSTSOCIALIST CONTEXT

Dejana Nedučin, Dušan Ristić, Vladimir Kubet

INTERACTIONS BETWEEN LIGHT AND ARCHITECTURE: AN EXPERIMENT USING MODELS AND PHOTOGRAPHS

Anita Stoilkov-Koneski

THE INTERPLAY OF MUSIC AND ARCHITECTURE: LAYERING OF SOUND AND SPACE

Anja Kostanjšak, Morana Pap

CULTURAL PATTERNS AND SENSITIVITY TODAY: FROM THE PHILOSOPHY TO THE TECHNOLOGY IN ARCHITECTURAL DESIGN PROCESS 
Małgorzata Kądziela, Anna Sachse-Rynkowska

PART III: PLACES, TECHNOLOGIES AND RELATED FIELDS

Big data, apps, social networks and microblogs in urban planning and design

PLACE COMPETITIVENESS EXPRESSED THROUGH DIGITAL DATA.

MEASURING THE PLACE ATTRACTIVENESS TRACKING THE GEOTAG

DATA VISUALS

Milena Vukmirovic, Eva Vanista Lazarevic

914

ROOM BOOK 2.0 - BRING BACK THE INFORMATION TO ITS PLACE

Christoph Breser, Stefan Zedlacher

THE INTERCONNECTED OBJECT: ARE YOU AT HOME IN A NETWORK?

Kalina Ntampiza, Polina Zioga

THE INTERACTION TIME IN A NETWORKED SOCIETY

Danijel Baturina

GOOGLE EARTH AS A MICROWORLD

Milena Zindović

TRANSPARENCY OF SCALE: GEOGRAPHICAL INFORMATION PROGRAM (GOOGLE EARTH) AND THE VIEW FROM BEYOND

Pavle Stamenović, Dunja Predić, Davor Ereš

Geodesy and modern cartography

ROBUST ESTIMATION APPLIED TO GEODETIC DATUM

TRANSFORMATION USING A METAHEURISTIC ALGORITHM

Mevlut Yetkin

THE STATE OF THE ART SURVEYING BY TECHNOLOGY OF THE TERRESTRIAL LASER SCANNING

Marko Pejić, Branko Božić, Verica Erić, Jelena Pandžić

ROLE OF CARTOGRAPHY IN MAKING A "SMART CITY": CASE STUDY OF INDJIJA

Dragutin Protić, Ivan Vučetić, Ivan Nestorov

MODERN CARTOGRAPHY IN PROJECT OF CENSUS

Maja Kalinić, Dragoljub Sekulović 
Mobility and technologies

PERSONAL RAPID TRANSIT - A SUSTAINABLE URBAN TRANSPORT SYSTEM

Ljupko Šimunović, Luka Novačko, Mario Ćosić

1011

FLIGHTPATH TO AN ENVIRONMENTAL FRIENDLY AIR TRANSPORT

Ivana Čavka, Olja Čokorilo, Slobodan Gvozdenović

1020

PRESERVATION OF PLACE-IDENTITY THROUGH URBAN

TRANSFORMATIONS BASED ON SUSTAINABLE FORMS OF

TRANSPORT

Miloš Kopić

1029

BELGRADE RIVERSIDE TRAFIC INTERCHANGES

Ksenija Stevanović, Milena Stevanović

1037

SUSTAINABLE URBAN MOBILITY PLANS IN EUROPE

Davor Brčić, Ljupko Šimunović, Marko Slavulj

1045

URBAN DEVELOPMENT IN BELGRADE IN THE CONTEXT OF GLOBAL TRENDS: CHANCES OF ILLEGAL HOUSING INTEGRATION

Biserka Mitrović, Miodrag Ralević, Branislav Antonić

1051

RE-THINKING INFRASTRUCTURE PROJECT FOR THE METROPOLIS: LABORATORY GRANADA

Juan Luis Rivas Navarro, Belén Bravo Rodríguez

1059

Public participation, e-governing and tehenology

COMMUNITY PARTICIPATION AND GREEN INFRASTRUCTURES: A

DELIBERATIVE EVALUATION METHOD

Saverio Miccoli, Fabrizio Finucci, Rocco Murro

RESULTS OF INTRODUCTION OF PARTICIPATORY TOOLS IN URBAN PLANNING IN SERBIA - 7 CASE STUDIES

Ratka Čolić, Harald Mueller

1075

WAYS TOWARDS A CITY OF NEW TECHNOLOGIES

Miodrag Ralevic, Tatjana Mrdjenovic, Natasa Krstic, Djemila Beganovic

1083

PARTICIPATION OF CITIZENS IN TOWN PLANNING PROCEDURES IN NEIGHBOURHOODS WITH FORMER REFUGEE AND DISPLACED

POPULATION IN PRIJEDOR, BOSNIA AND HERZEGOVINA

Rada Latinović

1090

THE ROLE OF INFORMATION AND COMMUNICATION TECHNOLOGY IN A VIRTUAL ORGANIZATION

Jelena Lukić

1098 


\title{
POTENTIALS AND LIMITATIONS FOR ENERGY REFURBISHMENT OF MULTI-FAMILY RESIDENTIAL BUILDINGS BUILT IN BELGRADE BEFORE THE WORLD WAR ONE
}

\section{Ljiljana Đukanović}

Faculty of Architecture, University of Belgrade, Bulevar kralja Aleksandra 73/II, Belgrade, Serbia, djuli@arh.bg.ac.rs

\section{Ana Radivojević}

Faculty of Architecture, University of Belgrade, Bulevar kralja Aleksandra 73/II, Belgrade, Serbia, ana@arh.bg.ac.rs

\section{Aleksandar Rajčić}

Faculty of Architecture, University of Belgrade, Bulevar kralja Aleksandra 73/II, Belgrade, Serbia, rajcic@arh.bg.ac.rs

\begin{abstract}
After the adoption of new Regulations on Energy Efficiency of Buildings, energy efficiency became the primary issue of the present building practice in Serbia, referring both to new buildings and to existing ones, among which refurbishment of buildings built before the World War One requires a special attention. Devastation of the building stock during the great wars of the $20^{\text {th }}$ century and the late start of the European model of urban development in the second half of the $19^{\text {th }}$ century in the most parts of Serbia are the main reasons that pre-1919 multi-family houses today represent about $1 \%$ of the total building stock. The rarity of the buildings of this age and their structures resulted with large number of them that are listed as cultural heritage, so any intervention on them, including those which are result of the adjustment to modern needs and building rules, becomes especially sensitive and complex. In particular, this refers to energy improvement measures which, according to new regulations, are an inevitable part of any building intervention. Having in mind all the mentioned aspects, and focused on the relevant examples of multi-family houses from Belgrade, this paper deals with investigation of potentials and limitations for energy refurbishment of buildings and building structures dating from the time before the World War One.
\end{abstract}

Keywords: energy refurbishment, multi-family residential buildings, built heritage

\section{INTRODUCTION}

Although by the time of its origin Belgrade represents the old European settlements, these historical facts are not visible through its architecture today. History of the city was marked by wartime destruction, fires, floods and other devastations, resulting 
with a small number of preserved buildings from the past, among which residential buildings built prior to the World War One represent only one percent of the total housing stock of the city. These circumstances distinguish Belgrade from other European capitals. The European model of urban development of the city started in the first half of the $19^{\text {th }}$ century. However, most of the preserved buildings of the period come from the second half of the $19^{\text {th }}$ century until the beginning of the World War One. Many of them have been protected as a cultural heritage, making the process of harmonization with modern standards in the field of thermal protection sensitive and complex.

\section{SELECTION OF THE SAMPLE OF BELgRAdE RESIDENTIAL ARCHITECTURE PRIOR TO THE WORLD WAR ONE}

Recently conducted research of building typology of housing stock in Serbia showed that existing pre-1919 multifamily residential buildings were massive, low-rise structures which rarely kept their authentic construction features. Having this in mind, a working class housing complex from Venizelos' Street in Belgrade was selected as an appropriate model for investigation of energy refurbishment potentials. The erection of the complex which, up to now, underwent just smallscale alterations, was financed by the Belgrade municipality was built in 1911 according to the design by the first woman architect in Serbia, Jelisaveta Načić. Planned for living of the poor civil servants and workers, this was the first settlement of social housing in Belgrade.
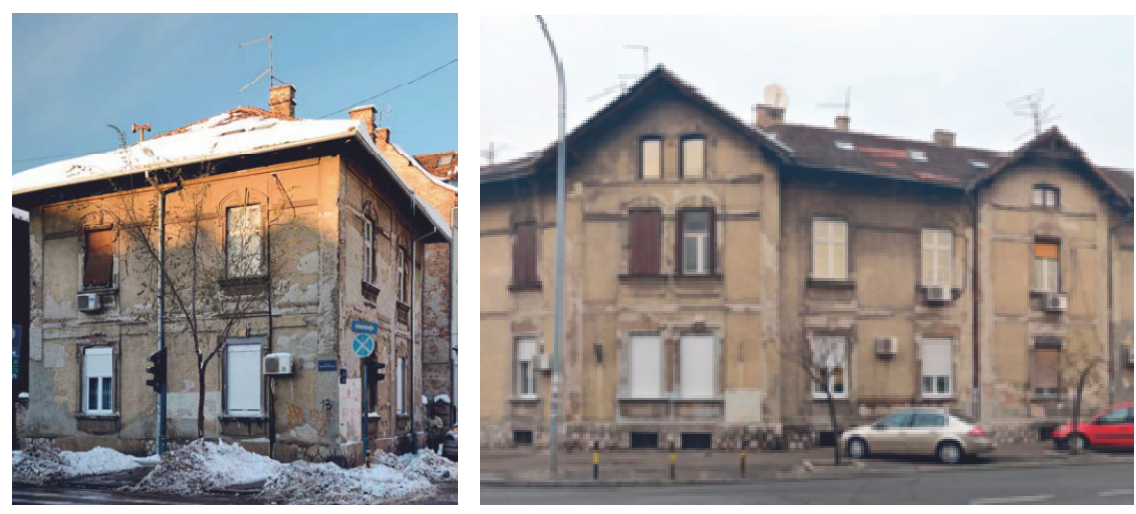

Figure 39: Housing complex in Venizelos' Street: free standing building (left) and lamela type building (right)

\section{Functional organization}

The complex was composed of three parts: two small free-standing buildings on the corners between which there was a residential lamela type building that comprises six entrances and represents multiplied form and organization of free-standing units. Buildings have a $\mathrm{Ba}+\mathrm{GF}+1$ scheme, with an unoccupied loft that was converted into a living space during the time. They are modest in volume, elements of form and 
decoration, expressing the designer's skill to avoid a potential impression of penury such houses might give due to the low investment in their construction. Freestanding buildings are of a square floor plan with a centrally positioned staircase placed between two identical small apartments of simple spatial organization. Apartments consisted of a room and a kitchen while the toilets were placed outside in a separate building in the yard. Elongated lamela type building is organized in a similar way, with two residential units per floor, but with toilets located inside the entrance area, symmetrically to the stairway zone, ensuring in this way that the apartments were fully fitted for the time of construction.

\section{Applied structures and building materials}

In the mid of $19^{\text {th }}$ century, the brick masonry became the dominant type of massive wall construction. Brick format was prescribed in 1896 by the Building law for the City of Belgrade in the tradition of the so-called Austrian format $(29 \times 14 \times 6,5 \mathrm{~cm})$. Following the building practice of the time, massive façade and load bearing walls of selected buildings had the thickness of $1 \frac{1}{2}$ or 1 brick.

As a compulsory fire protection measure imposed ty the building regulations, floor constructions above the unheated basement had to be massive. Therefore, the Prussian vault floor construction, a combination of steel beams and shallow brick vaults, was used in the buildings of the complex. This type of structure has pushed into the background conventional brick barrel vault. The use of reinforced concrete was limited to public buildings of a complex structure, while in other multi storey buildings its use was sporadic. In the analysed case, the staircase was solely of reinforced concrete, while the floor constructions to the loft were wooden, originally having a wooden decking and rammed earth layer above and straw-plaster ceiling below the wooden beams. The buildings had a typical wooden roof construction that formed the tile-clad pitched roof. Original windows were wooden, having double frame, with single glazed sash. Today, some of them are replaced with PVC windows. The façade was rendered with plaster with a shallow architectural decoration, but today it is in a poor condition. This could be the motive for energy refurbishment, which would inevitably lead to the improvement of the total living comfort.

\section{ENERGY IMPROVEMENT PROPOSAL}

During 2012, energy improvement measures that could be applied on the Serbian housing stock were investigated and discussed in the framework of Tabula project. $^{164}$ Among the total energy saving measures, those that refer to interventions on the building envelope, i.e. construction measures which will be analyzed. The principles that were established refer to the achievement of two levels of potential improvement of energy efficiency of buildings, the so called standard measures and enhanced measures.

\footnotetext{
${ }^{164}$ The IEE Project TABULA aimed at defining common principles for the creation of national
} typologies Approach for Building Stock Energy Assessment 
The first level of improvement considered construction interventions on the building thermal envelope that were typical of the local market, such as replacement of existing windows with new ones that fullfil the requirements of thermal regulations and addition of thermo insulating layers along the relevant wall and floor structures. The purpose of these measures was improvement of building energy performance for at least one energy efficiency class, which was in accordance with the current thermal regulation. The advanced level of energy improvement refered to the maximal possible measures that were in accordance to the features of a renovated building. They include installation of the most efficient, top quality windows available on the local market, as well as further thickening of additional thermo insulating layers.

The Regulations on Energy Efficiency of Buildings adopted in 2011 imposed significantly lower permited thermal transmittance values and introduced mandatory energy certification of buildings. Assessment of achieved energy efficiency of a building is expressed by the energy label, graded from A (most energy efficient) to $G$ (lower efficiency) which corresponds to calculated value of annual energy usage. The required specific heating energy demand per year $Q H, n d, \max$ $\left[\mathrm{kWh} /\left(\mathrm{m}^{2} \mathrm{a}\right)\right]$ for the new buildings corresponds to the energy class " $\mathrm{C}$ ", while, as already stated, existing ones should be improved for at least one energy rate.

Present condition of the buildings from Venizelos' Street does not fulfil requirements set by the Regulations. However, although analyzed residential buildings do not need an energy certifate, being protected as a cultural heritage, compatibility with the current requirements of energy efficiency contributes to the improvement of the living quality. In the present state, energy rating of the free-standing house ranks it in the "G" class, while lamela type building from the same complex is categorized as ${ } \mathrm{F}^{\prime}$ “ class, so they both significantly deviate from the permitted levels set for the new building.

\section{Improvements}

Proposed improvement measures in the first level of improvement were the same on both, free-standing and lamela type building. Standard improvement measures include additional $10 \mathrm{~cm}$ thermo insulating layer on the external side of the wall as well as bellow the floor construction to unheated basement. Double framed wooden windows should be replaced with wooden single framed, with double glazed low-E glass unit, filled with inert gas, while existing roof windows need to be replaced with aluminium framed roof windows with improved thermal break and glazed with the same type of glazing as improved ordinary windows. Applied measures of energy refurbishment contributed to reduction of U-values to prescribed limits for each of the elements that were the subject of improvement.

The second level of improvement strives to achieve the highest possible energy class of the building, involving all the elements that could contribute to energy saving and improving them to the level of prescribed limits (Table 1). This means addition of $20 \mathrm{~cm}$ thermo insulating layer on external side of the façade walls and $5 \mathrm{~cm}$ layer in the case of walls to unheated space (staircase and corridor). Below the 
adopted roof structure there is an additional $15 \mathrm{~cm}$ of thermo insulation, while floor construction to unheated basement requires addition of $15 \mathrm{~cm}$ thermo-insulating layer below the structure. Existing windows need to be replaced with PVC windows of six chamber profiles, glazed with triple low-E glass unit, filled with inert gas. Roof windows need to be of aluminium profiles with improved thermal break, glazed with the same type of glass unit as that of improved ordinary windows. Wooden doors need to be replaced with metal ones with an insulated leaf.

Table 1: Improvement interventions on some of the original elements of the thermal envelope

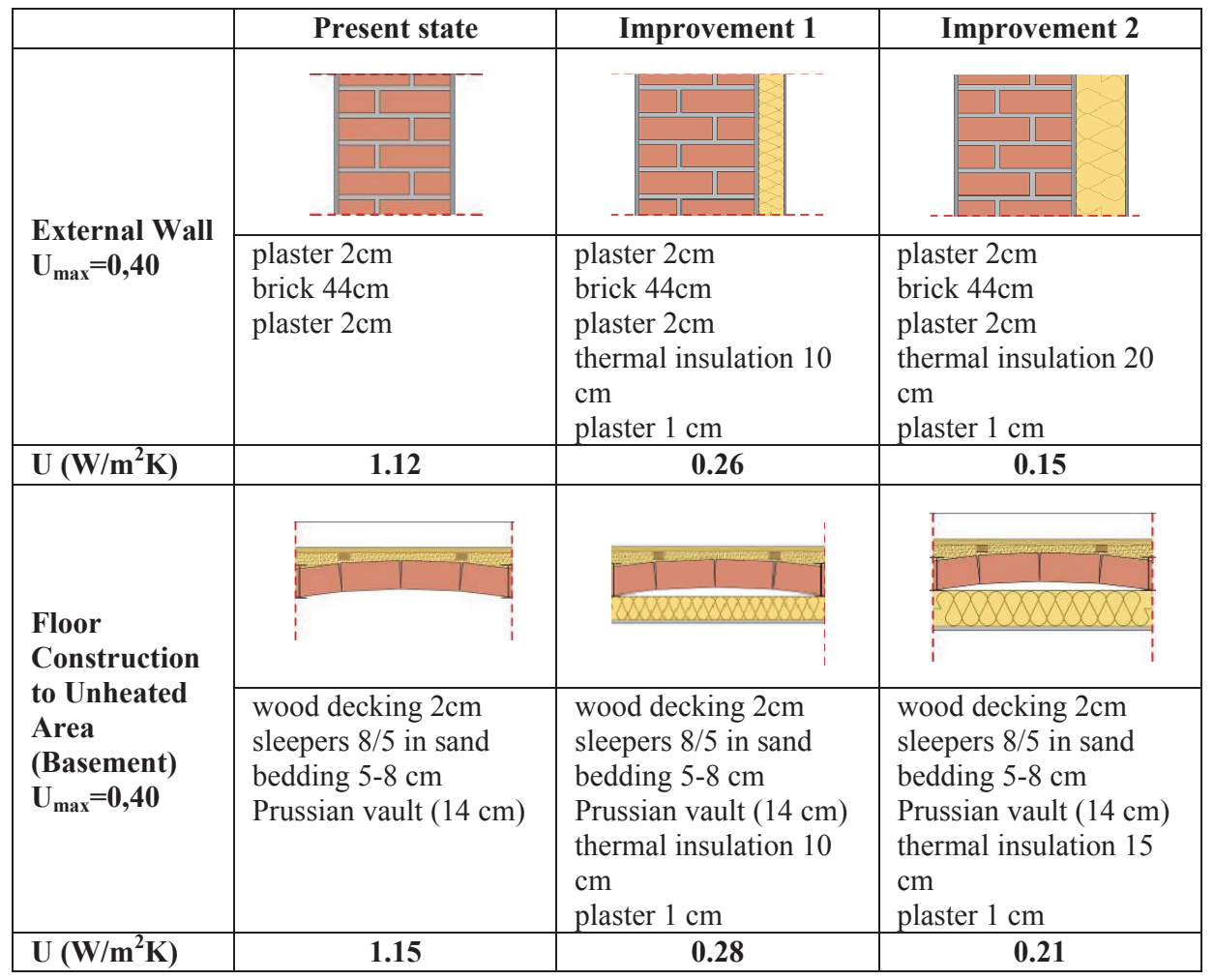

Achieved energy savings

The effects of two levels of energy improvement measures conducted on the case of the free-standing building are presented in Table 2. Diagram of heat loss through the elements of thermal envelope shows that the greatest savings are achieved by proposed façade wall insulation, which contribute the most to the total heat loss in the original building form, but decreasing four times within the first stage of improvement. Replacement of original windows also ensures significant reduction of heat loss to more than a half of the original value. Total heat loss after the implementation of the first level of energy saving measures is reduced more than a double (from 737,40 W/K to $329,55 \mathrm{~W} / \mathrm{K}$ ) and the same pattern is shown regarding the specific heating energy demand per year which is $52 \%$ reduced, i.e. from 210.29 
$\mathrm{kWh} / \mathrm{m}^{2}$ a to $101,20 \mathrm{kWh} / \mathrm{m}^{2} \mathrm{a}$. Therefore, the renovated building has the "D" energy class after the first level of improvement which is two energy classes higher than originally.

Table 2: Thermal envelope improvement - energy balance for the free-standing building

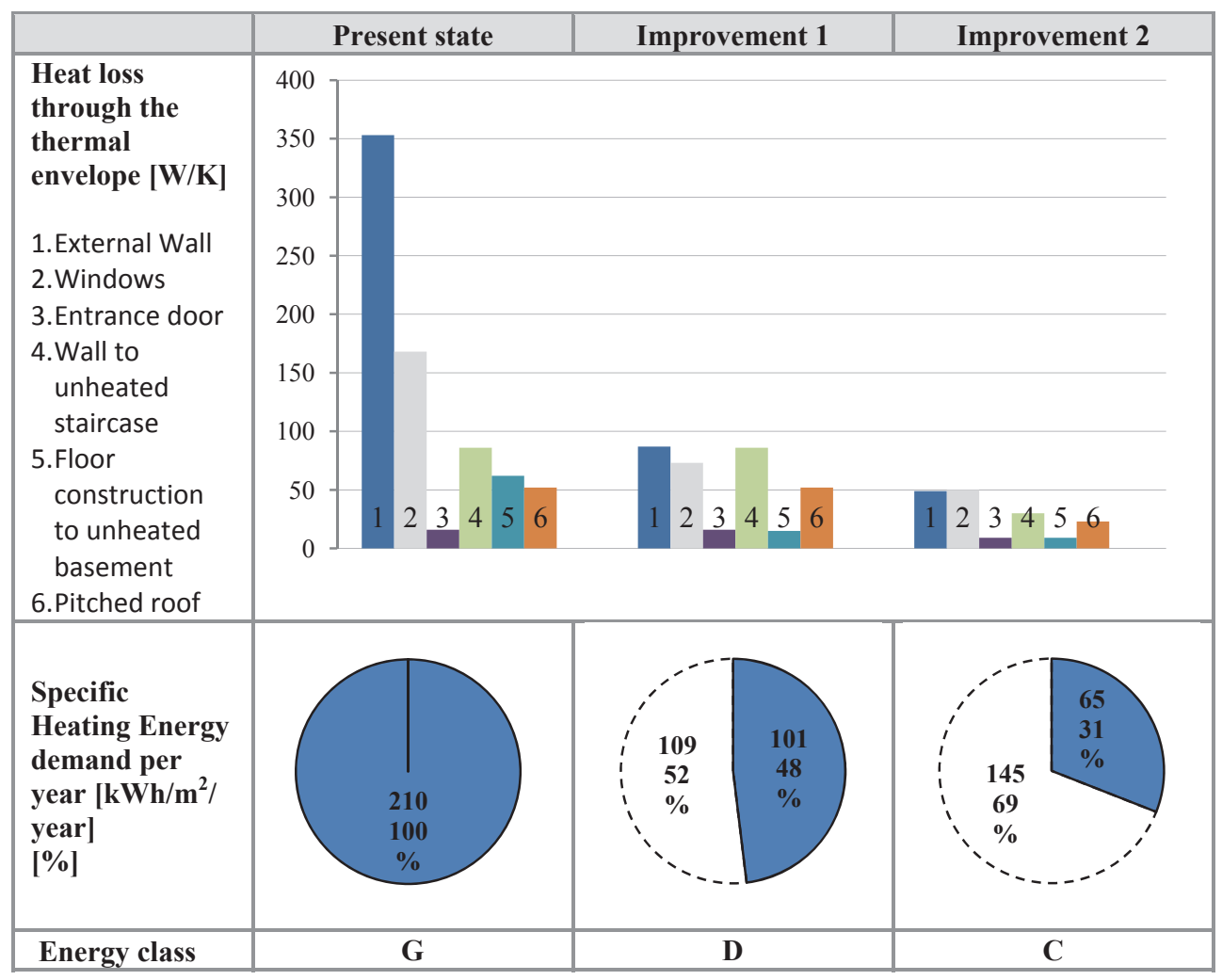

Through adequate interventions on all of the elements of thermal envelope, which were the improvement measures foreseen in the second level of improvement, total heat losses were four times lower than originally (from 737,40 W/K they were reduced to $170,94 \mathrm{~W} / \mathrm{K}$ ). The specific heating energy demand per year was reduced to $65,14 \mathrm{kWh} / \mathrm{m}^{2}$ a after this level of intervention, resulting with $69 \%$ of energy saving from the original state of the building. With such renovation the building would be rated as " $C$ " energy class and therefore in accordance with the regulations.

Other building that was analyzed represents a string composed of six residential units that are in shape and in size equal to the freestanding building. However, due to its size, volume and wall to window ratio, this building as a whole has much favorable energy performances than the free-standing one and higher energy class "F“. Table 3 shows the effects of the two levels of energy improvement of the lamela type building. 
As in the case of the free-standing building, the greatest savings are achieved by proposed façade wall insulation, followed with window replacement. After the first phase of energy renovation, heat losses through façade walls were reduced four times, while those through windows became half of original ones. Total heat loss after this phase was reduced to almost a half (from $2648,6 \mathrm{~W} / \mathrm{K}$ to $1443,18 \mathrm{~W} / \mathrm{K}$ ), as well as the specific heating energy demand per year which was decreased from $164,39 \mathrm{kWh} / \mathrm{m}^{2}$ a to $76,9 \mathrm{kWh} / \mathrm{m}^{2}$ a, resulting with $53 \%$ of energy saving and "D“ energy class of the renovated building.

Table 3: Thermal envelope improvement - energy balance for the lamela type building

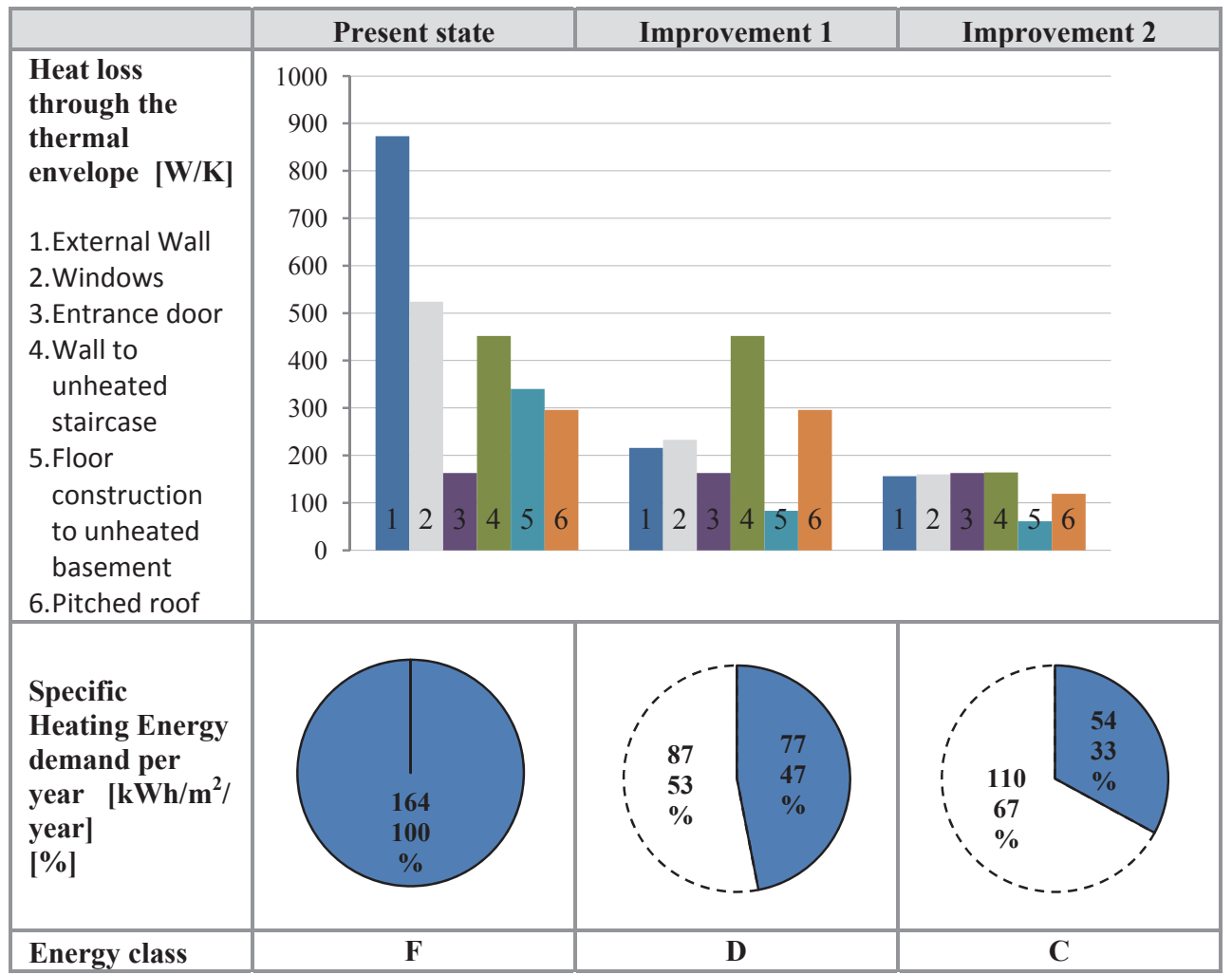

In the second phase of energy renovation, proposed intervention on all the elements of the thermal envelope resulted with triple reduction of the total heat loss compared to the original state (from $2648,6 \mathrm{~W} / \mathrm{K}$ to $822,19 \mathrm{~W} / \mathrm{K}$ ). The specific heating energy demand per year was reduced to $53,84 \mathrm{kWh} / \mathrm{m}^{2}$ a, which is $67 \%$ less than in the original state. The building was transformed into the energy class " $\mathrm{C}$ " building, becoming in this way in accordance with the regulations. 


\section{CONCLUSIONS}

Analysis of selected buildings from the early $20^{\text {th }}$ century through two phases of energy refurbishment shows that the standard level of intervention does not meet the more severe requirements of the energy efficiency of buildings. However, the implementation of new demands becomes possible only by applying the enhanced measures where interventions are done on all elements of the thermal envelope through application of the maximal extent of thermal protection measures. The chosen examples were basically more convenient for energy refurbishment due to their shallow architectural decoration on a façade that enabled their reconstruction by addition of external thermo insulating layer. Unlike them, buildings with rich façade mouldings that were typical for the time require interventions from the internal side of the building which could be am aggravating factor in achieving requirements of the present energy efficiency regulations. Possible solution in such cases could be found in appropriate application of some innovative thermo insulating materials which provide a high level of thermal protection with thin layers of materials, and/or allow internal application.

\section{REFERENCES}

Vuksanović Macura, Zlata. 2012. Život na ivici. Beograd: Orion art.

Поповић Јовановић, Милица et al. 2013. Атлас вишепородичних зграда Србије. Београд: Архитектонски факултет Универзитета у Београду, GIZ Deutsche Gesellschaft fur Internationale Zusammenarbeit.

Поповић Јовановић, Милица et al. 2013. Национална типологија стамбених зграда Cрбије. Београд: Архитектонски факултет Универзитета у Београду, GIZ Deutsche Gesellschaft fur Internationale Zusammenarbeit.

„Правилник о енергетској ефикасности зграда“. Службени гласник Републике Србије 6р.61, 2011.

„Правилник о условима, садржини и начину издавања сертификата о енергетским својствима зграда“. Службени гласник Републике Србије 6p.61, 2011. 